\title{
Determinant of Physical Violence at Household Level in Indonesia
}

\author{
Dyah Hapsari Ekonugraheni ${ }^{1}$, Sofyan Effendi ${ }^{2}$ \& Mery Yanti ${ }^{3}$ \\ ${ }^{12}$ Department of Sociology, Sriwijaya University, INDONESIA \\ ${ }^{2}$ Department of Public Administration, Sriwijaya University, INDONESIA \\ E-mail: dyahhapsari@ fisip.unsri.ac.id
}

\begin{abstract}
This article examine the influence of type of residence (X1), trust (X2), security conditions (X3), religious activities (D1), market operations (X4), number of village midwives (X5), household access to electricity (X6), the main crops of villagers (D2), and the number of poor households (X7) against physical violence at the household level in Indonesia using the logistic regression method. The source of research data comes from the 5th Wave of the Indonesian Family Life Survey (IFLS). The results of the bivariate analysis indicate that only $\mathrm{X} 1, \mathrm{X} 6, \mathrm{D} 2, \mathrm{X} 7$ could be included in multivariate analysis because it is significantly related to $\mathrm{Y}$. Although it is not significantly related to $\mathrm{Y}, \mathrm{X} 4$ and $\mathrm{X} 5$ still including in multivariate analysis because of $\mathrm{p}<0.25$. The other three independent variables, $\mathrm{X} 2, \mathrm{X} 3$, D1, cannot be included in multivariate analysis because they do not significantly contribute to $\mathrm{Y}$ and $\mathrm{p}>$ 0.25 . The final logistic regression model only contained independent variables and can estimate Y by $6.74 \%$ significantly, $\mathrm{X} 2(4)=28.79, \mathrm{p}<0.01$. The final model shows that only D2 and X6 have a negative relationship and explaining $\mathrm{Y}$ by $-47.3 \%$ and $64 \%$, respectively. Whereas X4 and X7, have a positive relationship and explain Y by $78.1 \%$ and $110.1 \%$. This finding strengthens the influence of economic factors on physical phenomena on women at the household level. This article recommends to the all-party that concerns to physical violence at the household level, especially government institution at all level, to improve family food resilience, reduce poverty, and increase household electrification while providing media literacy to citizens.
\end{abstract}

Keywords: physical violence, IFLS, electrification, household poverty, Indonesia

\section{Introduction}

According to the National Commission on Violence Against Woman or Komnas Perempuan (2018), the number of cases of violence against women (VAW) reached 348,446 cases. This number increased compared to the previous year, which was only 259,150 cases. The most prominent types of VAW are domestic violence at a personal domain $(9,609$ cases $/ 71 \%$ ); violence against women in the public domain $(3,528$ cases $/ 26 \%)$. Of the total domestic violence at the public domain, $76 \%$ were in the form of sexual violence namely sexual abuse (911 cases), sexual harassment (704 cases), rape (699 cases), and sexual intercourse (343 cases) while VAW in state domain reached 217 cases (1.8 percent). Furthermore, the most prominent forms of VAW in the 
personal domain were physical violence $(3,982$ cases or $41 \%$ ), sexual violence $(2,979$ cases or $31 \%)$, psychological violence $(1,404$ cases or $15 \%)$ and economic violence $(1,244$ cases or $13 \%$ ). If referring to the context of social relations, the violence at personal domain that often occurs is violence against wives $(5,167$ cases or 54 percent), dating violence (1,873 cases or 19 percent), violence against girls $(2,227$ cases or 23 percent), and the remainder are ex-husband violence, ex-boyfriends, and violence against domestic workers. The most worrying phenomenon is the incest phenomenon $(1,210$ cases $)$ where the offender is the biological father is reaching 425 cases (Komnas Perempuan, 2018).

The data above indicates that household institutions are no longer a haven for their residents as contained in the phrase "my house is my paradise' (baiti jannati), which is popular among Muslims in Indonesia. According to previous research, there are no Indonesian researchers who have tried to explain the relationship between type of residence (X2), degree of security village (X3), religious activity (D1), market operation (X4), the number of village midwife (X5), household access to electricity (X6), the main crops of villagers (D2), and the number of poor household (X7) and the VAW quantitatively. This research is essential as a scientific contribution to achieve gender equity, which is one of the targets of the Sustainable Development Goals (SDGs).

Formally, the term VAW first appeared in the resolution of the General Assembly of the United Nations (UN) Number A/RES/48/104 concerning the Declaration on the Elimination of Violence against Women in 1994. This document defines VAW as each gender-based acts of violence that can endanger, or potentially cause, suffering, threats, coercion, and deprivation of physical, sexual, psychological freedom for women arbitrarily, both in their private lives and in the public sphere (United Nations, 1994). Where did the source of the VAW come from? There are at least three theories that try to explain this phenomenon: social learning theory, gender theory and masculinity, and feminism theory (Johnson, Ollus, \& Nevala, 2008). According to social learning theory, VAW actions are the result of imitating the actions of others in a particular social setting. Learning resources can be family members or individuals in the broader social environment (for example, community, organization, community). When someone is exposed to a VAW in childhood (for example, just looking at or becomes a victim), then he tends to use violence in every development of his age.

There are at least three theories that try to explain this phenomenon: social learning theory, gender theory and masculinity, and feminism theory (Johnson et al., 2008).
According to social learning theory, VAW actions are the result of imitating the actions of others in a particular social setting. Learning resources can be family members or individuals in the wider social environment (for example, community, organization, community). When someone is exposed to a VAW in childhood (for example, just looking at or becomes a victim), then he tends to use violence in every development of his age.

Like social learning theory, gender theory and masculinity argue that the VAW is a product of socialization about the role of gender in specific cultures that occur during childhood and supports the domination and control of men over women. VAW is a vehicle for men to express the hegemony of masculinity towards women who are trapped in a gender-biased division of labor. This theory also sees it as a competition for social status among men in expressing their masculinity. Because of differences in access to resources between men, not all men can show their masculinity. In this situation, marginal men will construct violence differently from men who have a higher social class. Marginal men who are unable to express their masculinity in legitimate ways tend to construct aggressive forms of violence.

Unlike the two theories in the above, feminism theory describes VAW as a product of a patriarchal system that creates and perpetuates gender inequality (unbalanced power relations between men and women) in all aspects of social life. This patriarchal system has two components: structure and ideology. Social structure refers to institutionalized social relations in various social institutions such as family, law, religion, education, and health whereas ideology refers to the beliefs and views of many people who accept and support the patriarchal system as something natural and good for the whole society.

The forms of VAW in society can be explained by the framework of the World Health Organization (WHO) which divides violence into three types: violence against oneself, violence between people, and collective violence. Violence against oneself consists of suicidal behavior and self-harming behavior. Violence between people can occur at two levels: family level and community level. At the family level, violence can take the form of violence against children, spouses, and parents. At the community level, violence can be done by acquaintances or strangers, while collective violence can occur in the realm of social, political, and economic life. All forms of this violence can lead to physical violence, sexual violence (except suicide and self-harm), psychological violence, and other derivative violence (WHO, 2002).

According to WHO (2002), the causes of violence are very varied and depend on the unit of analysis 
(individuals, social relations, communities). Table 1 simplifies WHO's arguments about the causes of violence based on the classification of types of violence. Although WHO does not explicitly mention the term VAW, Table 1 can also be applied to understand the phenomenon of VAW. Because women are always present as victims in every type and level of violence, according to Table 1, the VAW is called domestic violence when violence against adolescents, children, partners, parents, sexual and self-abuse occurs in the household.

\begin{tabular}{|c|c|c|c|c|}
\hline $\begin{array}{l}\text { Type } \\
\text { of } \\
\text { violenc } \\
\text { e / } \\
\text { Risk } \\
\text { factor }\end{array}$ & $\begin{array}{l}\text { Individu } \\
\text { al }\end{array}$ & $\begin{array}{l}\text { Social } \\
\text { relation }\end{array}$ & $\begin{array}{l}\text { Commun } \\
\text { ity }\end{array}$ & Society \\
\hline $\begin{array}{l}\text { Adoles } \\
\text { cent }\end{array}$ & $\begin{array}{l}\text { Biologic } \\
\text { al } \\
\text { character } \\
\text { istic and } \\
\text { personali } \\
\text { ty }\end{array}$ & $\begin{array}{l}\text { Influenc } \\
\text { es of } \\
\text { peers } \\
\text { and } \\
\text { family } \\
\text { member } \\
\text { s }\end{array}$ & $\begin{array}{l}\text { Gang, } \\
\text { narcotics, } \\
\text { firearms } \\
\text { and social } \\
\text { integratio } \\
\text { n }\end{array}$ & $\begin{array}{l}\text { Social and } \\
\text { demograph } \\
\text { ic change, } \\
\text { income } \\
\text { inequality, } \\
\text { political } \\
\text { structure, } \\
\text { and } \\
\text { cultural } \\
\text { factors }\end{array}$ \\
\hline $\begin{array}{l}\text { Childr } \\
\text { en }\end{array}$ & $\begin{array}{l}\text { Age, } \\
\text { gender, } \\
\text { special } \\
\text { character } \\
\text { of child }\end{array}$ & $\begin{array}{l}\text { Structur } \\
\text { e, } \\
\text { resource } \\
\text { s, size } \\
\text { and } \\
\text { composi } \\
\text { tion of } \\
\text { family, } \\
\text { parental } \\
\text { personal } \\
\text { ity, } \\
\text { history } \\
\text { of } \\
\text { family } \\
\text { violence } \\
\text {, social } \\
\text { isolation } \\
\text {, partner } \\
\text { violence }\end{array}$ & $\begin{array}{l}\text { Poverty } \\
\text { and social } \\
\text { capital }\end{array}$ & $\begin{array}{l}\text { Cultural } \\
\text { values, } \\
\text { economic } \\
\text { forces, sex } \\
\text { and } \\
\text { income } \\
\text { injustice, } \\
\text { public } \\
\text { policies on } \\
\text { children } \\
\text { and } \\
\text { families, } \\
\text { social } \\
\text { welfare } \\
\text { systems, } \\
\text { war and } \\
\text { social } \\
\text { conflict. }\end{array}$ \\
\hline $\begin{array}{l}\text { Partne } \\
\mathbf{r}\end{array}$ & $\begin{array}{l}\text { Age, } \\
\text { drunks, } \\
\text { depressi } \\
\text { on, } \\
\text { personali } \\
\text { ty, } \\
\text { educatio } \\
\text { n level, } \\
\text { income } \\
\text { level, }\end{array}$ & $\begin{array}{l}\text { Marriag } \\
\mathrm{e} \\
\text { conflict } \\
\text { and } \\
\text { instabilit } \\
\text { y, male } \\
\text { dominan } \\
\text { ce in the } \\
\text { family, } \\
\text { economi }\end{array}$ & $\begin{array}{l}\text { Weak } \\
\text { communit } \\
\text { y } \\
\text { sanctions, } \\
\text { poverty } \\
\text { and social } \\
\text { capital }\end{array}$ & $\begin{array}{l}\text { Traditional } \\
\text { gender } \\
\text { norms and } \\
\text { social } \\
\text { norms that } \\
\text { support } \\
\text { violence }\end{array}$ \\
\hline
\end{tabular}

\begin{tabular}{|c|c|c|c|c|}
\hline & $\begin{array}{l}\text { and the } \\
\text { violent } \\
\text { experien } \\
\text { ces in } \\
\text { childhoo } \\
\text { d }\end{array}$ & $\begin{array}{l}\mathrm{c} \\
\text { pressure } \\
\text { s, and } \\
\text { family } \\
\text { poverty }\end{array}$ & & \\
\hline Parent & $\begin{array}{l}\text { Personali } \\
\text { ty, } \\
\text { alcohol, } \\
\text { mental } \\
\text { health }\end{array}$ & $\begin{array}{l}\text { Low } \\
\text { parental } \\
\text { attention } \\
\text { towards } \\
\text { children, } \\
\text { child } \\
\text { migratio } \\
\mathrm{n} \text { to } \\
\text { other } \\
\text { areas, } \\
\text { caregive } \\
\text { r } \\
\text { depressi } \\
\text { on, } \\
\text { caregive } \\
\text { r } \\
\text { destructi } \\
\text { ve and } \\
\text { aggressi } \\
\text { ve } \\
\text { behavior } \\
\text { low } \\
\text { privacy. }\end{array}$ & $\begin{array}{l}\text { Social } \\
\text { isolation, } \\
\text { cultural } \\
\text { traditions } \\
\text { and } \\
\text { norms, } \\
\text { matrilinea } \\
1 \text { and } \\
\text { patrilineal } \\
\text { systems, } \\
\text { family } \\
\text { economic } \\
\text { conditions }\end{array}$ & $\begin{array}{l}\text { Social } \\
\text { isolation, } \\
\text { cultural } \\
\text { traditions } \\
\text { and norms, } \\
\text { matrilineal } \\
\text { and } \\
\text { patrilineal } \\
\text { systems, } \\
\text { family } \\
\text { economic } \\
\text { conditions }\end{array}$ \\
\hline Sex & $\begin{array}{l}\text { Age, } \\
\text { alcohol, } \\
\text { narcotics } \\
\text {, past } \\
\text { trauma, } \\
\text { many } \\
\text { sex } \\
\text { partners, } \\
\text { sex } \\
\text { workers, } \\
\text { educatio } \\
\text { n level, } \\
\text { poverty }\end{array}$ & $\begin{array}{l}\text { The } \\
\text { couple's } \\
\text { aggressi } \\
\text { ve } \\
\text { attitude, } \\
\text { family } \\
\text { environ } \\
\text { ment, } \\
\text { patriarc } \\
\text { hal } \\
\text { relations } \\
\text {, and } \\
\text { family } \\
\text { self- } \\
\text { esteem } \\
\end{array}$ & $\begin{array}{l}\text { Poverty, } \\
\text { employm } \\
\text { ent, law } \\
\text { and } \\
\text { policy, } \\
\text { tolerance } \\
\text { and } \\
\text { communit } \\
\text { y } \\
\text { sanctions } \\
\text { against } \\
\text { perpetrato } \\
\text { rs }\end{array}$ & $\begin{array}{l}\text { Social } \\
\text { norms, } \\
\text { laws and } \\
\text { policies } \\
\text { regarding } \\
\text { sexual } \\
\text { violence } \\
\text { and gender } \\
\text { justice, and } \\
\text { crime }\end{array}$ \\
\hline $\begin{array}{l}\text { Onesel } \\
\text { f }\end{array}$ & $\begin{array}{l}\text { Psycholo } \\
\text { gical } \\
\text { conditio } \\
\text { ns and } \\
\text { marital } \\
\text { status }\end{array}$ & $\begin{array}{l}\text { Genetic } \\
\text { factors, } \\
\text { family } \\
\text { history }\end{array}$ & $\begin{array}{l}\text { Availabili } \\
\text { ty of } \\
\text { suicide, } \\
\text { residence, } \\
\text { unemploy } \\
\text { ment, } \\
\text { immigrati } \\
\text { on status, } \\
\text { religion } \\
\text { and } \\
\text { economic } \\
\text { conditions }\end{array}$ & \\
\hline Collect & & & & Democrati \\
\hline
\end{tabular}




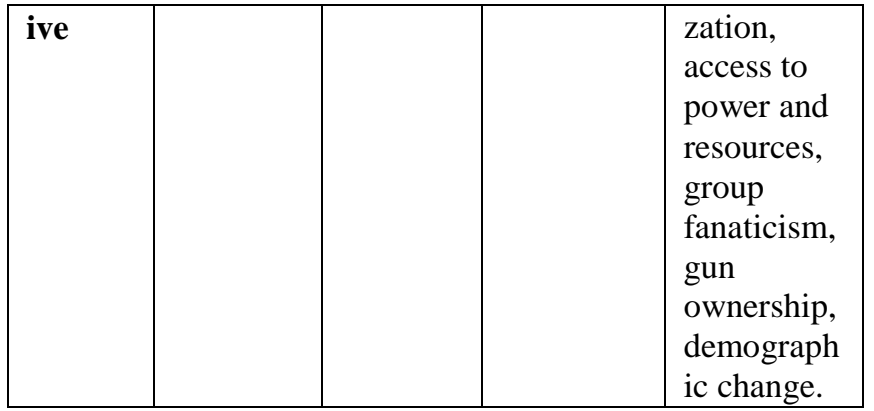

Table 1 The cause of violence

Source: WHO (2002)

Previous research has identified several factors that contribute to domestic violence practices, for example, social capital (Benavides, León, Etesse, Espezúa, \& Stuart, 2019; Bruederle, Delany-Moretlwe, Mmari, \& Brahmbhatt, 2019; Daoud, Sergienko, O'Campo, \& Shoham-Vardi, 2017; Noaparast, 2011; Rojas \& Stickley, 2014), environmental security (Flood \& Pease, 2009; Lockie, 2011; Pinchevsky \& Wright, 2012; Sampson, 1997), economic factors (Babu \& Kar, 2009, 2010; Benson, Fox, DeMaris, \& Van Wyk, 2003; Everingham, 2002; Farmer \& Tiefenthaler, 2006; MilesDoan, 1998), religiosity (Eidhamar, 2018; Faizah, 2013; Fatmariza, 2012; Nur, 2012; Wahyuni, 2008), electrification (Fernández-Baldor, Lillo, \& Boni, 2015; Sievert, 2015).

In Indonesia, previous researchers' findings on domestic violence are also varied and not much different from WHO documentation. As Table 2 shows, the causes of VAW in Indonesia can be classified into four factors. First, the offender factors include low levels of education, gambling and debt, drugs, polygamy, alcohol, jealousy, access to firearms, depression, gang involvement, gunfights, and types of work. Second, the victim factor consists of jealousy, menstruation, questioning male authority/actions, social discrimination, and the law. Third, the factor of social relations between perpetrators and victims, which includes the quality of social relations, time with family, type of marriage, gender-based relations. Fourth, household context factors consisting of patriarchal culture, household finances and economy, number of household members, religious values, local cultural values, family institution norms, internalization of gender norms, and the living environment.

\begin{tabular}{|l|l|l|}
\hline No & Author & Cause \\
\hline 1. & $\begin{array}{l}\text { Aisyah (2012) dan } \\
\text { Aisyah \& Parker } \\
\text { (2014) }\end{array}$ & $\begin{array}{l}\text { Women's efforts to question or } \\
\text { challenge men's power or } \\
\text { authority, polygamy, gender- } \\
\text { based division of labor, } \\
\text { financial issues, and alcohol. }\end{array}$ \\
\hline
\end{tabular}

\begin{tabular}{|c|c|c|}
\hline 2. & Arifianti et al., (2017) & $\begin{array}{l}\text { The work of the offender, } \\
\text { quality of social relations with } \\
\text { the offender, the past } \\
\text { experience, household } \\
\text { economy, and time with } \\
\text { family. } \\
\text { perpetrator }\end{array}$ \\
\hline 3. & Asal \& Brown (2010) & $\begin{array}{l}\text { Quality of democracy and } \\
\text { economic inequality }\end{array}$ \\
\hline 4. & Asmarany (2007) & Gender bias \\
\hline 5. & Blackburn (1999) & Economic and political crises \\
\hline 6. & Fulu et al., (2013) & $\begin{array}{l}\text { Gender-based relations, past } \\
\text { traumatic experiences, } \\
\text { depression, alcohol, low level } \\
\text { of education, poverty, gang } \\
\text { involvement, gun battles. }\end{array}$ \\
\hline 7. & Gusliana (2010) & $\begin{array}{l}\text { Patriarchal culture, the crush } \\
\text { of the family's economy, } \\
\text { neighborhood, and type of } \\
\text { work. }\end{array}$ \\
\hline 8. & $\begin{array}{l}\text { Hayati, Emmelin, \& } \\
\text { Eriksson (2014) }\end{array}$ & $\begin{array}{l}\text { Man's perspective on } \\
\text { masculinity }\end{array}$ \\
\hline 9. & $\begin{array}{l}\text { Hayati, Högberg, } \\
\text { Hakimi, Ellsberg, \& } \\
\text { Emmelin (2011) }\end{array}$ & $\begin{array}{l}\text { The demographic and personal } \\
\text { characteristics of the husband, } \\
\text { and women's economic } \\
\text { dependence }\end{array}$ \\
\hline 10. & Misa (2013) & $\begin{array}{l}\text { Economic factors, jealousy } \\
\text { and alcohol }\end{array}$ \\
\hline 11. & Nilan et al., (2014) & $\begin{array}{l}\text { Economic pressure and } \\
\text { conservative religious views. }\end{array}$ \\
\hline 12. & $\begin{array}{l}\text { Nur Hayati et al., } \\
(2013)\end{array}$ & $\begin{array}{l}\text { Internalization of gender } \\
\text { norms }\end{array}$ \\
\hline 13. & $\begin{array}{l}\text { Rofiah }(2017) \& \\
\text { Parker (2016) }\end{array}$ & $\begin{array}{l}\text { Patriarchal culture and } \\
\text { ideology of family }\end{array}$ \\
\hline 14. & Venning (2010) & $\begin{array}{l}\text { Gender stereotypes, cultural } \\
\text { norms and family institutions, } \\
\text { legal and social } \\
\text { discrimination, poverty, and } \\
\text { economic factors. }\end{array}$ \\
\hline
\end{tabular}


Table 2 Cause violence against woman in Indonesia

However, to the best of the researchers' knowledge, there is no research on VAW in Indonesia that makes statistical models about the contribution of type of residence, trust, level of security, religious activities, market operations, number of village midwives, household access to electricity, the main plant of population, and the number of poor households to VAW.

\section{Methods}

This study uses a quantitative approach and using data from the 5th wave of the Indonesian Family Life Survey (IFLS) collected by RAND Corporation in collaboration with Survey Meter at the end of 2014 and early 2015 in 13 provinces in Indonesia. IFLS is a cross-sectional and longitudinal data survey that has been carried out several times (1993, 1997, 2000, 2007, 2015) and aims to obtain data on the characteristics of households in Indonesia, particularly on the economy, health, education, and social protection aspect (Strauss, Witoelar, \& Sikoki, 2016). Specifically, for this study, the data came from the community facility questionnaire at the village level.

The population of IFLS 5 is the entire population of Indonesia. Its sample is selected using the stratified random sampling technique, which refers to the SUSENAS sampling framework in 1993. The total number of IFLS 5 sample is 16,204 households, 50,418 people, and 640 community leaders at the village level (Strauss et al., 2016). Research respondents who are interviewed using the community facilities questionnaire were residents or villagers who had a social role as senior teachers/headmaster, health practitioners, youth activists, religious leaders, party activists at the village level, or local entrepreneurs. The number of community leaders who were successfully interviewed by IFLS 5 with the Informant Book reached 640 people and spread in 13 provinces. Data is analyzed using binary logistic regression with STATA 15 software. The variables of this study consisted of one dependent variable and nine independent variables. Table 3 shows the operationalization of the research variables.

\begin{tabular}{|l|l|}
\hline \multicolumn{2}{|l|}{ Dependent variable } \\
\hline $\begin{array}{l}\text { Physical } \\
\text { violence in } \\
\text { household } \\
\text { level (Y) }\end{array}$ & $\begin{array}{l}\text { Measuring through the question: "In the last } 12 \\
\text { months, has there been a case of physical } \\
\text { violence at the household level in this } \\
\text { rural/urban village?" Data changed into a } \\
\text { dummy variable }(1=\text { yes and } 0=\text { no). }\end{array}$ \\
\hline \multicolumn{2}{|l|}{ Independent variable } \\
\hline
\end{tabular}

\begin{tabular}{|c|c|}
\hline $\begin{array}{l}\text { Type of } \\
\text { residence } \\
\left(\mathrm{X}_{1}\right)\end{array}$ & $\begin{array}{l}\text { Status of district/city where the respondent } \\
\text { lives in }(1=\text { urban and } 0=\text { rural }) \text {. }\end{array}$ \\
\hline Trust $\left(\mathrm{X}_{2}\right)$ & $\begin{array}{l}\text { Measuring through the Likert scales with } \\
\text { consists of seven statement. Each statement has } \\
\text { four answer: very agree, agree, disagree, } \\
\text { strongly disagree. Total score of respondents } \\
\text { recoded into a dummy variable ( } 1=\text { high trust } \\
\text { and } 0=\text { low trust). }\end{array}$ \\
\hline $\begin{array}{l}\text { Level of } \\
\text { village } \\
\text { security } \\
\left(\mathrm{X}_{3}\right)\end{array}$ & $\begin{array}{l}\text { The perception of village community leaders } \\
\text { about security conditions at the village level. } \\
\text { This variable is measured by the question, } \\
\text { "according to your assessment, what is the } \\
\text { condition of the security in this village?" which } \\
\text { has four choices of answers: very secure, } \\
\text { secure, insecure, and very insecure. } \\
\text { Respondents' answers are simplified into two } \\
\text { categories (secure and insecure) and converted } \\
\text { to dummy variables ( } 1=\text { secure and } 0= \\
\text { insecure). }\end{array}$ \\
\hline $\begin{array}{l}\text { Religious } \\
\text { activity } \\
\left(\mathrm{D}_{1}\right)\end{array}$ & $\begin{array}{l}\text { The perception of village community leaders } \\
\text { about the participation of villagers in religious } \\
\text { activity. This variable is measured by the } \\
\text { question: what is the proportion of rural/urban } \\
\text { residents who are participating in religious } \\
\text { activities regularly?" which have three } \\
\text { answers: } \leq 25 \% \text { (low), } 25 \%-75 \% \text { (moderate), } \\
\text { and }>75 \% \text { (high). }\end{array}$ \\
\hline $\begin{array}{l}\text { Market } \\
\text { operation } \\
\left(\mathrm{X}_{4}\right)\end{array}$ & $\begin{array}{l}\text { Perception of village community leaders about } \\
\text { the implementation of market operations } \\
\text { (cooking oil, kerosene, sugar, and rice) in their } \\
\text { villages. This variable is measured by the } \\
\text { question "in the past } 12 \text { months, is there a } \\
\text { market operation program in this village that } \\
\text { sells nine basic food (sembako) at affordable } \\
\text { prices or below market prices?" which has two } \\
\text { answer options: yes (1) and no (0). }\end{array}$ \\
\hline $\begin{array}{l}\text { Number of } \\
\text { villages } \\
\text { midwives } \\
\left(\mathrm{X}_{5}\right)\end{array}$ & $\begin{array}{l}\text { The number of midwives assigned by the } \\
\text { government or opening practices in the village. } \\
\text { This variable recoded into two categories: } \leq 3 \\
\text { people }(0) \text { and } \geq 4 \text { people }(1)\end{array}$ \\
\hline $\begin{array}{l}\text { Household } \\
\text { access to } \\
\text { electricity } \\
\left(\mathrm{X}_{6}\right)\end{array}$ & $\begin{array}{l}\text { The proportion of households that have access } \\
\text { and use electricity. This variable recoded into } \\
\text { two categories: } \leq 95 \text { percent }(0) \text { and } \geq 95 \\
\text { percent }(1) \text {. }\end{array}$ \\
\hline $\begin{array}{l}\text { The main } \\
\text { crops of } \\
\text { villagers }\end{array}$ & $\begin{array}{l}\text { The three main crops }(1=\text { paddy, } 2=\text { corn; and } \\
3=\text { no crops }) \text { in the village in the last } 12 \\
\text { months. }\end{array}$ \\
\hline
\end{tabular}




\begin{tabular}{|l|l|}
\hline$\left(\mathrm{D}_{2}\right)$ & $\mid$ \\
\hline Number of & The number of low-incomes families in the \\
poor & village. This variable recoded into two \\
household & $\begin{array}{l}\text { categories: }<500 \text { household }(0) \text { and }>500 \\
\text { household }(1) .\end{array}$ \\
\hline
\end{tabular}

Table 3 Operationalization of research variable

Data processing and analysis in this study consist of several stages. The first stage is data transformation where the researchers' merging, recode, cleaning and calculating the final score of the Likert scale, and so on. Second, partial regression analysis to select variables using the Forward method. This study consisted of one dependent variable and nine independent variables. Only variables that have a strong relationship ( $p \leq 0.25$ ) with the dependent variable will be included in the logistic regression. The independent variables which have $p>0.25$ will be excluded from the model. This value is obtained by performing the Wald test. Third, multivariate analysis using binary logistic regression. Fourth, the interpretation and discussion of the logistic regression model produced in this study. Fifth, testing the goodness-offit the final model using the Hosmer-Lemeshow test.

\section{Result}

\subsection{Characteristic of respondent}

The respondents of this study are community leaders who live in villages and come from a variety of social roles. The total number of respondents successfully interviewed with the Book of Public Informant questionnaire totaled 640 people with the following composition: senior teachers/headmaster (18.28\%), health practitioners (13.13\%), youth activists (18.28\%), religious leaders $(19.06 \%)$, party activists (15\%), and local entrepreneurs (16.25\%). These respondents dispersed in several provinces: (a) 5 provinces in Sumatra Island $(21.22 \%)$; (b) 6 provinces in Java Islands $(59.82 \%)$; (c) 2 provinces in Bali and Nusa Tenggara Islands (9.64\%); (d) 2 provinces in Sulawesi Island (5.14\%); and (e) 1 province on Kalimantan Island $(4.18 \%)$. The proportion of respondents from Java islands remained higher as the implications of sampling that were proportional to the population. The research respondents who lived in urban areas reached 210 people $(52.63 \%)$, and those who lived in a rural area were 189 people $(47.37 \%)$. In terms of gender, male respondents numbered 485 people $(77.97 \%)$, and female respondents numbered 137 people (22.03\%). Most respondents have educated in diploma - post-graduated $(57.40 \%)$. The second position is occupied by respondents who have high school/vocational/equivalent education (28.94\%). The third position is occupied by respondents who have an education < junior high school $(11.58 \%)$. The rest are those who are educated in Islamic boarding schools and others (for example, disability school).

\subsection{Bivariate analysis}

The prevalence of physical violence at the household level in Indonesia reaches 16.79 percent per year (Y). The results of the bivariate analysis show that only $\mathrm{X} 1$ (the type of residence), X6 (household access to electricity), the main crops of villagers (D2), the number of poor households (X7) can be included in the multivariate analysis because it is significantly related to Y. Although X4 (market operation) and $\mathrm{X} 5$ (the number of village midwives) have no relationship with $\mathrm{Y}$, these two variables will also be included in multivariate analysis because of $\mathrm{p}<0.25$. Other independent variables, namely X2 (trust), X3 (village security conditions), D1 (religious activities), which do not significantly contribute to $\mathrm{Y}$ (domestic violence against women in the household) and a value of $p>0.25$ cannot be included in the model logistic regression. A summary of the bivariate analysis is shown in Table 4.

\begin{tabular}{|c|c|c|c|c|}
\hline No & Independent variable & $X^{2}$ & $p$ & $\phi$ \\
\hline 1. & $\begin{array}{l}\text { The main crops of } \\
\text { villagers }\left(D_{2}\right)\end{array}$ & 11.72 & $0.00<0.25$ & 0.17 \\
\hline 2. & $\begin{array}{l}\text { Household access to } \\
\text { electricity }\left(\mathrm{X}_{6}\right)\end{array}$ & 8.21 & $0.00<0.25$ & $(0.14)$ \\
\hline 3. & $\begin{array}{l}\text { Number of poor } \\
\text { household }\left(\mathrm{X}_{7}\right)\end{array}$ & 6.43 & $0.01<0.25$ & $(0.13)$ \\
\hline 4. & Type of residence $\left(\mathrm{X}_{1}\right)$ & 5.49 & $0.01<0.25$ & 0.12 \\
\hline 5. & $\begin{array}{l}\text { Number of villages } \\
\text { midwives }\left(\mathrm{X}_{5}\right)\end{array}$ & 2.91 & $0.08<0.25$ & 0.09 \\
\hline 6. & Market operation $\left(\mathrm{X}_{4}\right)$ & 2.78 & $0.09<0.25$ & 0.08 \\
\hline 7. & $\begin{array}{l}\text { Level of village } \\
\text { security }\left(\mathrm{X}_{3}\right)\end{array}$ & 0.79 & $0.37>0.25$ & 0.04 \\
\hline 8. & Religious activity $\left(\mathrm{D}_{1}\right)$ & 0.32 & $0.85>0.25$ & 0.03 \\
\hline 9. & Trust $\left(\mathrm{X}_{2}\right)$ & 0.01 & $0.90>0.25$ & 0.01 \\
\hline
\end{tabular}

Table 4 Summary of bivariate analysis

\subsection{Multivariate analysis}

This study produces the final model of logistic regression which only consists of four independent variables: the main crops of villagers (D2), household access to electricity (X6), number of poor household (X7), and market operation (X4). 
The final model of logistic regression can be formulated as follows: $\mathrm{Y}=-9.1232+$ the main crops of villagers (D2) * $1.0272+$ household access to electricity $(\mathrm{X} 6) * 0.0769+$ the number of poor household $(\mathrm{X} 7) * 0.0006$. This final model can explain $\mathrm{Y}$ as much as $0.0674(6.74 \%)$ significantly, $\mathrm{X} 2$ $(4)=28.79, p<0.01$. Outside of 6.74 percent is the influence of various independent variables that have not been included in this research. The final model shows that only the numbers of poor household (D7) have a positive relationship with the $\mathrm{Y}$ (domestic violence occurrence). Three other variables, household access to electricity (X6), the number of poor household (X7), market operation (X4), have a negative relationship with Y (domestic violence occurrence). All of them affect $Y$ (domestic violence occurrence) with different of significance level, $\mathrm{p}<0.01$ for D2, X6, and X7 and $\mathrm{p}<0.1$ for X4. However, only the main crops of villagers (D2) were able to explain the variable $\mathrm{Y}$ (domestic violence occurrence) of $6.74 \%$. Two other independent variables are only able to explain the variable $\mathrm{Y}$ (domestic violence occurrence) of 8.0 percent (household access to electricity/X6) and 0.1 percent (low-income families/X7) (see Table 5).

If the analysis is focused on the categories within independent variable, then only category within X6 (have access to electricity) and X7 (the number of poor household) has significant at $\mathrm{p}<0.01$. While $\mathrm{X} 4$ (market operation) has significant at $\mathrm{p}<0.05$ and $\mathrm{D} 2$, especially paddy, has significant at $\mathrm{p}<0.1$. D2 (paddy) and X7 (the number of poor household) has a positive relationship, while X4 (market operation) and X6 (household access to electricity) has a negative relationship with $\mathrm{Y}$ (physical violence in household level) (see Table 5).

\begin{tabular}{|c|c|c|}
\hline \multirow[t]{2}{*}{ Independent variable } & \multicolumn{2}{|c|}{$\begin{array}{l}\text { Physical violence in } \\
\text { household level (Y) }\end{array}$} \\
\hline & $\begin{array}{l}\text { Without } \\
\text { category }\end{array}$ & $\begin{array}{c}\text { With } \\
\text { category }\end{array}$ \\
\hline \multicolumn{3}{|l|}{ The main crops of villager $\left(D_{2}\right)$} \\
\hline \multirow[t]{2}{*}{ Paddy } & & $0.783 *$ \\
\hline & & $(-0.444)$ \\
\hline \multirow[t]{2}{*}{ Corn } & & -0.511 \\
\hline & & $(-0.547)$ \\
\hline \multicolumn{3}{|l|}{ Household access to electricity $\left(\mathrm{X}_{6}\right)$} \\
\hline Have access electricity $<95 \%$ & & $\begin{array}{c}- \\
1.025^{* * *}\end{array}$ \\
\hline
\end{tabular}

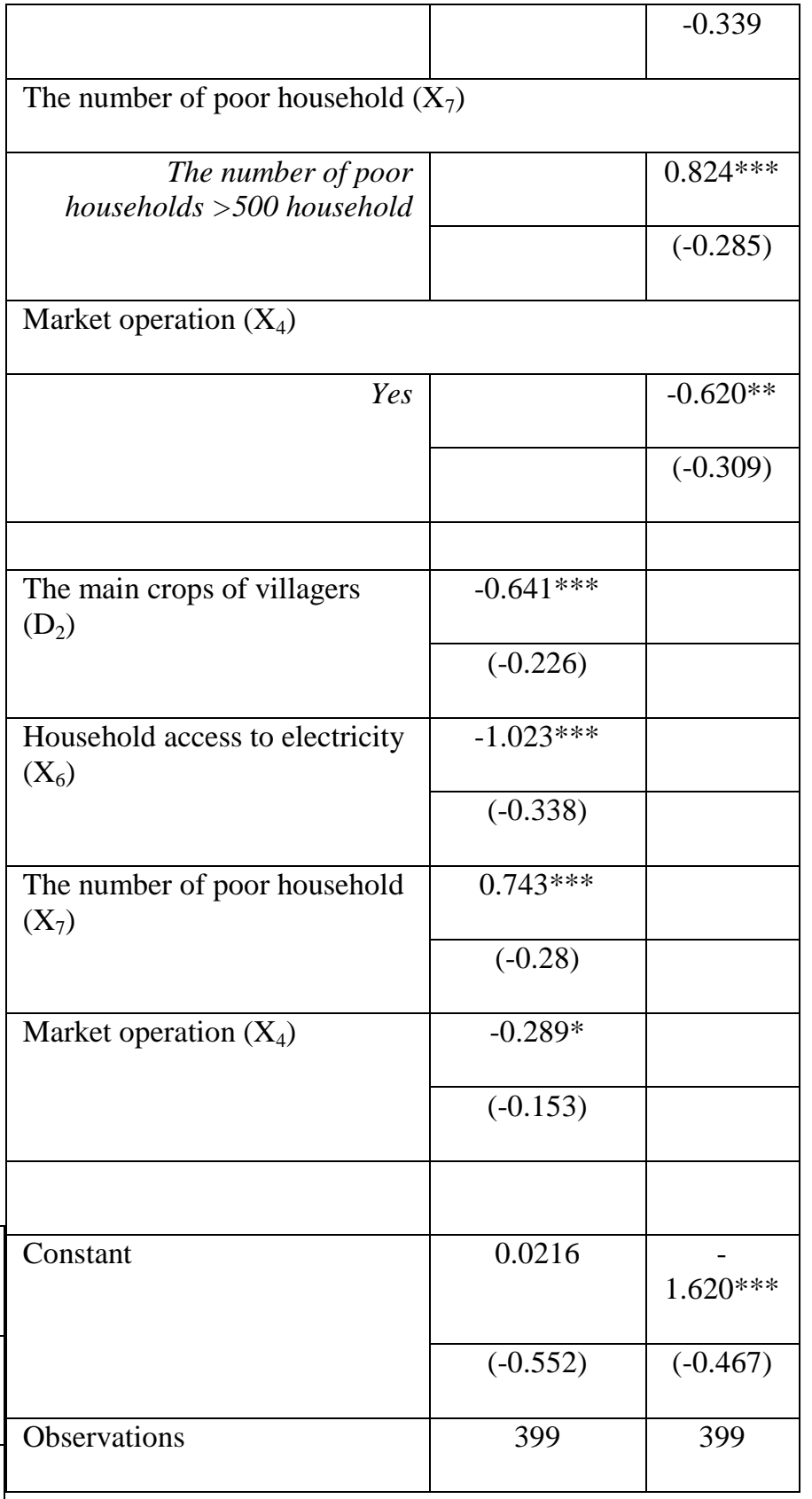

Standard errors in parentheses $* * * \mathrm{p}<0.01, * * \mathrm{p}<0.05, * \mathrm{p}<0.1$

Table 5 The final model of logistic regression

\section{Discussion}

The 5th wave of Indonesia Family Life Survey (IFLS) data used in this study showed that of the 399 respondents interviewed with the Informant Book questionnaire, 332 respondents $(82.21 \%)$ stated they had not seen the phenomenon of physical violence in the household during the last 12 months. There were only 67 respondents (16.79\%) who claimed to see the phenomenon of physical violence in 
the household in the last 12 months. Initially, the researchers presumed that the incidence of physical violence against women as much as 16.79 percent above was due to the influence of all independent variables identified by this study (X1, X2, X3, D1, X4, X5, X6, D2, and X7)

This opinion arises because of the results of previous research confirms the influence of these independent variables on the phenomenon of physical violence in the household, for example trust or social capital (Benavides et al., 2019; Bruederle et al., 2019; Daoud et al., 2017; Noaparast, 2011; Rojas \& Stickley, 2014), village security (Flood \& Pease, 2009; Lockie, 2011; Pinchevsky \& Wright, 2012; Sampson, 1997), access to electricity (Fernández-Baldor et al., 2015; Sievert, 2015), type of residence (Gusliana, 2010), religiosity (Eidhamar, 2018; Faizah, 2013; Fatmariza, 2012; Nur, 2012; Wahyuni, 2008), economic factors (Babu \& Kar, 2009, 2010; Benson et al., 2003; Everingham, 2002; Farmer \& Tiefenthaler, 2006; Miles-Doan, 1998). While the number of village midwife variable represents the presence of government institutions as health service providers, including responding to the problem of domestic violence at the grassroots which is part of the health problem.

The researchers' guess missed. Of the nine independent variables identified by researchers as predictors of the occurrence of physical violence in household level (Y), only four independent variables significantly affect Y, namely: the main crop produced by the population, household access to electricity, the number of poor households, market operations. This finding confirms previous research which states that household access to electricity and economic factors (number of poor households, main crops of villagers, market operations) as predictors of the occurrence of physical violence in households. This study weakens the results of previous research which states that trust or social capital, the security of the village of residence, religiosity, and the existence of village midwives as health service providers is a cause of incidents of physical violence in the household.

Among the independent variables that significantly influence the incidence of physical violence in the household (Y), two independent variables have a negative relationship: D2 (the main crops of villagers) and X6 (household access to electricity). While others variable, X7 (number of poor households), and X4 (market operation), has a positive relationship. The results of this relationship are: first, the probability of physical violence occurring in the household (Y) will decrease by $47.3 \%$ if the villagers were planting the rise as a primary crop. The amount of contribution of the main crops of villagers in the final model of logistic regression, especially paddy or rice, confirms the economic factors of the family as the cause of physical violence in the household. Paddy commodity is a symbol of food which is part of basic human needs. Food needs are a source of energy that makes humans able to do many activities. Because of the importance of food for humans, it is not surprising that God Almighty himself ordered that: "then let a man pay attention to his food" (Surah 'Abasa [80]: 24). Conversely, losing access to food will trigger starvation, which will result in death.

Second, the odds of physical violence in the household (Y) will decrease by $64 \%$ in the village with electrification more than $<95 \%$. This finding contradicts with the results of Sievert's (2015) in Africa, which states that electrification can play an essential role in eliminating physical violence in the household, especially against women from intimate partners. Electricity allows women in the household to access various information from television that influences their thoughts and actions. On the contrary, this research confirms that the lower level of electrification, the lower the prevalence of physical violence in the household. At first glance, this finding is illogical. However, if analyzed in-depth, this finding is very logical. Because of those who do not have a television (standard equipment in every household that can access electricity) not only avoid various information that contains violence content but have plenty of time to build quality social interactions at the household level.

According to the latest Nielsen study, Indonesians people spend 4 hours 53 minutes for watching television (Fajar, 2019). Programs watched include news broadcasts, infotainment, soap operas, and variety shows. In addition to news broadcasts, the quality of broadcast programs titled infotainment, soap operas, and variety shows will significantly depend on the program manager at each television station. That is, not all these programs are bad. KPI's (Indonesian Broadcasting Commission, Komisi Penyiaran Indonesia or KPI) research results show that viewers show positive responses to religious, tourism/cultural programs, and vice versa for soap opera and infotainment programs (Pratomo, 2015). Because the television remote is in the hands of audiences at home, the process of consuming television broadcasts will significantly depend on media literacy and information literacy at the household level. In a situation of low media literacy in Indonesia and broadcast programs filled with soap operas and infotainment, not accessing television will be better than accessing television because it will avoid the undesirable effects of television broadcasting. 
Third, the odds of physical violence in households (Y) reaches $110.3 \%$ in villages which have poor households more than $>500$ families. In other words, poverty is a trigger for physical violence in the household (Y). Poverty, in all its shapes and sizes, will weaken the human ability to live properly as human beings. In Indonesia, most women are "household queens" who struggle with unpaid domestic activities. They should provide the daily nutritional needs of their family members from their husband's income. When the husband's income is low, the wife's ability to provide for household members is also limited. Typically, this condition will lead to disputes between husband and wife, which results in physical violence against women.

Fourth, the odds of physical violence in the household $(\mathrm{Y})$ reaches $78.3 \%$ in the village, which is held as the location of the nine-basic food market operation. Market operations are the government instruments to strengthen family food security which is weakened due to various market shocks (for example, inflation) or due to natural cycles (for example, drought, disasters, etc.) which damage family food security. These findings focus not on market operations, but the location of market operations themselves. The village selected by the government as the location of market operations have the odds of $78.3 \%$ of physical violence in the household.

According to Regulation of the Ministry of Trade No. 04/M-DAG/PER/1/2012 concerning Usage of Government Rice Reserves for Price Stability, market operations are government actions in order to deal with surges in rice prices that occur in certain areas during specific periods using reserves government rice. The location chosen by government institutions is the location affected by the surge in rice prices. If a location is very vulnerable to changes in the price of rice, then it indicates that households in that location are not yet secure economically. The household is not poor but will be poor due to the turmoil in the price of rice. In other words, these households are vulnerable to market price fluctuations, crop failure, termination of employment, illness, and so on (Pritchett, Suryahadi, \& Sumarto, 2000).

Based on the above findings and fit with the steps of the United Nations that place zero hunger as the second objective of SDGs, this article recommends to government institution at all level to strengthen resilience Indonesian family food through cross-sectoral development programs. Government, for example, could open a new land, intensification, and financing the agriculture sector. While in the downstream, the government could continue controlling food prices, restructuring the market, and food trades reforms. Government institutions at all levels are encouraged to continue developing policies and programs that are antipoverty and pro-poor. It is not only fit with the 1 st objective of SDGs (no poverty) but also match with the mandate of the constitution of the Republic of Indonesia as stipulated in the Preamble of the 1945 Constitution: "... protect all Indonesians and all of Indonesia's blood spills and to advance public welfare, educate the nation ... ". Poverty is a phenomenon that is difficult to overcome in Indonesia because it continues to evolve dynamically. Until 2018, for example, the number of poor people in Indonesia still perched at 25.67 million people or 9 percent of Indonesia's total population of 267 million people. Because the number of poor people is positively related to the phenomenon of physical violence in the household, the change in the number of poor people will directly impact the incidence of physical violence in the household even though only 1 percent. Government institutions are also advised to increase electrification while providing media literacy education to citizens to be smart in producing, distributing, and consuming a variety of information originating from mass communication channels and information and communication technology equipment.

This research has several weaknesses. First, the respondents of this study were community leaders and not community members involved in incidents directly of physical violence in the household, whether as perpetrators, victims, or mediators. In the future, those who are directly involved in incidents of physical violence in the household need to become research respondents. Second, as the dependent variable, physical violence in the household is not yet focused. The victim is not apparent. Victims of physical violence in the household can hit children, mothers, wives, husbands, parents, and other members of nucleus families. In the future, research respondents need to be focused again. Finally, because the final model of logistic regression produced by this study is only can explain the incidence of physical violence in the household by 6.74 percent, the independent variables need to be adding. Some independent variables that are not significant in this study can be put back again into the next logistic regression model.

\section{Acknowledgment}

The Rector of Sriwijaya University is fully funded this research based on the Decree of the Rector of Sriwijaya University number 0015/UN9/SK.LP2M.PT/2019, dated June 21, 2019.

\section{References}

[1] Aisyah, S. (2012). Rereading Patriarchal Interpretations on the Quran from Hadith Perspective in the Eve of Law No. 23/2004 on the Elimination of Domestic Violence. 
Journal of Indonesian Islam, 6(1), 48-75. https://doi.org/10.15642/JIIS.2012.6.1.48-75

[2] Aisyah, S., \& Parker, L. (2014). Problematic Conjugations: Women's Agency, Marriage and Domestic Violence in Indonesia. Asian Studies Review, 38(2), 205223. https://doi.org/10.1080/10357823.2014.899312

[3] Arifianti, L. A. A., Jayanegara, K., Gandhiadi, G. K., \& Kencana, E. N. (2017). Identifikasi Faktor-Faktor Pemicu Kekerasan dalam Rumah Tangga di Kota Denpasar. EJurnal Matematika, 6(1), 83-89.

[4] Asal, V., \& Brown, M. (2010). A cross-national exploration of the conditions that produce interpersonal violence. Politics and Policy, 38(2), 175-192. https://doi.org/10.1111/j.1747-1346.2010.00234.X

[5] Asmarany, A. I. (2007). Bias Gender Sebagai Prediktor Kekerasan Dalam Rumah Tangga. Jurnal Psikologi, 35(1), 1-20. https://doi.org/10.1007/978-88-470-2838-8

[6] Babu, B. V, \& Kar, S. K. (2009). Domestic violence against women in eastern India: a population-based study on prevalence and related issues. BMC Public Health, 9(129), 1-15. https://doi.org/10.1186/1471-2458-9-129

[7] Babu, B. V, \& Kar, S. K. (2010). Domestic violence in Eastern India: Factors associated with victimization and perpetration. Public Health, 124(3), 136-148. https://doi.org/10.1016/j.puhe.2010.01.014

[8] Benavides, M., León, J., Etesse, M., Espezúa, L., \& Stuart, J. (2019). Exploring the association between segregation and physical intimate partner violence in Lima, Peru: The mediating role of gender norms and social capital. SSM - Population Health, 7, 100338. https://doi.org/https://doi.org/10.1016/j.ssmph.2018.1003 $\underline{38}$

[9] Benson, M. L., Fox, G. L., DeMaris, A., \& Van Wyk, J. (2003). Neighborhood Disadvantage, Individual Economic Distress and Violence Against Women in Intimate Relationship. Journal of Quantitative Criminology, 19(3), 207-235. https://doi.org/10.1023/A:1024930208331

[10] Blackburn, S. (1999). Gender violence and the Indonesian political transition. Asian Studies Review, 23(4), 433-448. https://doi.org/10.1080/10357829908713249

[11] Bruederle, A., Delany-Moretlwe, S., Mmari, K., \& Brahmbhatt, H. (2019). Social Support and Its Effects on Adolescent Sexual Risk Taking: A Look at Vulnerable Populations in Baltimore and Johannesburg. Journal of Adolescent Health, 64(1), 56-62. https://doi.org/https://doi.org/10.1016/i.jadohealth.2018.0 7.004

[12] Daoud, N., Sergienko, R., O’Campo, P., \& ShohamVardi, I. (2017). Disorganization Theory, Neighborhood Social Capital, and Ethnic Inequalities in Intimate Partner Violence between Arab and Jewish Women Citizens of
Israel. Journal of Urban Health, 94(5), 648-665. https://doi.org/10.1007/s11524-017-0196-4

[13] Eidhamar, L. G. (2018). 'My Husband is My Key to Paradise.' Attitudes of Muslims in Indonesia and Norway to Spousal Roles and Wife-Beating. Islam and ChristianMuslim Relations, 29(2), 241-264. https://doi.org/10.1080/09596410.2017.1405636

[14] Everingham, C. (2002). Engendering Time workplace flexibility. Time and Society, 11(2), 335-351. https://doi.org/10.1177/0961463X02011002009

[15] Faizah, N. (2013). Nusyuz: Antara Kekerasan Fisik Dan Seksual. Al-Ahwal, 6(2), 113-128.

[16] Fajar, T. (2019). Studi Nielsen: Pemirsa Indonesia Habiskan 5 Jam Nonton TV, 3 Jam Berselancar di Internet. Retrieved August 13, 2019, from https://economy.okezone.com/read/2019/03/05/320/2025 987/studi-nielsen-pemirsa-indonesia-habiskan-5-jamnonton-tv-3-jam-berselancar-di-internet?page $=2$

[17] Farmer, A., \& Tiefenthaler, J. (2006). Review of Social Economy An Economic Analysis of Domestic Violence. Review of Social Economy, 55(3), 337-358. https://doi.org/10.1080/00346769700000004

[18] Fatmariza, F. (2012). Fenomena Kekerasan Terhadap Perempuan di Dalam Rumah Tangga (Pandangan Mubalig). Humanus, 12(2), 172-180. https://doi.org/10.24036/jh.v11i2.2166

[19] Fernández-Baldor, Á., Lillo, P., \& Boni, A. (2015). Gender, Energy, and Inequalities: A Capabilities Approach Analysis of Renewable Electrification Projects in Peru. In S. Hostettler, A. Gadgil, \& E. Hazboun (Eds.), Sustainable Access to Energy in the Global South (pp. 193-204). Cham: Springer International Publishing. https://doi.org/10.1007/978-3-319-20209-9_17

[20] Flood, M., \& Pease, B. (2009). Factors Influencing Attitudes to Violence Against Women. Trauma, Violence, \& Abuse, 10(2), 125-142. https://doi.org/10.1177/1524838009334131

[21] Fulu, E., Jewkes, R., Roselli, T., \& Garcia-Moreno, C. (2013). Prevalence of and factors associated with male perpetration of intimate partner violence: Findings from the UN multi-country cross-sectional study on men and violence in Asia and the Pacific. The Lancet Global Health, 1(4), e187-e207. https://doi.org/10.1016/S2214109X(13)70074-3

[22] Gusliana, H. (2010). Penyebab Terjadinya Kekerasan Dalam Rumah Tangga (KDRT) Yang Dilakukan Oleh Suami terhadap Isteri di Kota Pekanbaru. Jurnal Ilmu Hukum, 1(1), 80-93.

[23] Hayati, E. N., Emmelin, M., \& Eriksson, M. (2014). "We no longer live in the old days": a qualitative study on the role of masculinity and religion for men's views on violence within marriage in rural Java, Indonesia. 


\section{RedWhitepress}

Global Conferences Series: Social Sciences, Education and Humanities (GCSSSEH), Volume 2, 2019

BMC Women's Health, 14(1), 58. https://doi.org/10.1186/1472-6874-14-58

[24] Hayati, E. N., Högberg, U., Hakimi, M., Ellsberg, M. C., \& Emmelin, M. (2011). Behind the silence of harmony: Risk factors for physical and sexual violence among women in rural Indonesia. BMC Women's Health, 11. https://doi.org/10.1002/app.10449

[25] Johnson, H., Ollus, N., \& Nevala, S. (2008). Violence Against Women: An International Perspective. New York, USA: Springer.

[26] Komnas Perempuan. (2018). Tergerusnya Ruang Aman Perempuan dalam Pusaran Politik Populisme: Catatan Kekerasan Terhadap Perempuan Tahun 2017. Jakarta, Indonesia: Komnas Perempuan.

[27] Lockie, S. (2011). Intimate partner abuse and women's health in rural and mining communities. Rural Society, 20(2), 198-215. https://doi.org/10.5172/rsj.20.2.198

[28] Miles-Doan, R. (1998). Violence between spouses and intimates: Does neighborhood context matter? Social Forces, 77(2), 623-645. https://doi.org/10.1093/sf/77.2.623

[29] Misa, L. (2013). Studi Kriminologi Penyelesaian Kekerasan dalam Rumah Tangga. KANUN: Jurnal Ilmu Hukum, 60(15), 297-312.

[30] Nilan, P., Demartoto, A., Broom, A., \& Germov, J. (2014). Indonesian Men's Perceptions of Violence Against Women. Violence Against Women, 20(7), 869888. https://doi.org/10.1177/1077801214543383

[31] Noaparast, E. B. (2011). Social Capital, Family Supports and Mental Health among a Female Group in Tehran. Procedia - Social and Behavioral Sciences, 30, 2449-2451.

https://doi.org/https://doi.org/10.1016/j.sbspro.2011.10.4 77

[32] Nur Hayati, E., Eriksson, M., Hakimi, M., Högberg, U., \& Emmelin, M. (2013). 'Elastic band strategy': women's lived experience of coping with domestic violence in rural Indonesia. Global Health Action, 6(1), 18894. https://doi.org/10.3402/gha.v6i0.18894

[33] Nur, R. (2012). Nilai-Nilai Budaya Lokal dan Kekerasan Terhadap Perempuan di Kabupaten Donggala Sulawesi Tenggah. Humaniora, 24(1), 37-49. Retrieved from suska.ac.id/index.php/marwah/article/view/470

[34] Parker, L. (2016). The theory and context of the stigmatisation of widows and divorcees (janda) in Indonesia. Indonesia and the Malay World, 44(128), 726. https://doi.org/10.1017/S1816968600019939

[35] Pinchevsky, G. M., \& Wright, E. M. (2012). The Impact of Neighborhoods on Intimate Partner Violence and Victimization. Trauma, Violence, and Abuse, 13(2), 112 132. https://doi.org/10.1177/1524838012445641
[36] Pratomo, Y. (2015). Ini acara televisi terbaik dan terburuk versi KPI. Retrieved August 13, 2019, from https://www.merdeka.com/peristiwa/ini-acara-televisiterbaik-dan-terburuk-versi-kpi.html

[37] Pritchett, L., Suryahadi, A., \& Sumarto, S. (2000). Quantifying Vulnerability to Poverty: A Proposed Measure, Applied to Indonesia (Policy Research Working Paper No. 2437). Washington D.C., USA.

[38] Rofiah, N. (2017). Kekerasan Dalam Rumah Tangga dalam Perspektif Islam. Wawasan: Jurnal Ilmiah Agama Dan Sosial Budaya, 2(1), 31-44. https://doi.org/10.15575/jw.v2i1.829

[39] Rojas, Y., \& Stickley, A. (2014). Informal social capital in childhood and suicide among adolescent and young adult women: A cross-sectional analysis with 30 countries. Women's Studies International Forum, 42, 18 .

https://doi.org/https://doi.org/10.1016/j.wsif.2013.10.009

[40] Sampson, R. J. (1997). Neighborhoods and Violent Crime: A Multilevel Study of Collective Efficacy. Science, 277(5328), 918-924. https://doi.org/10.1126/science.277.5328.918

[41] Sievert, M. (2015). Rural Electrification and Domestic Violence in Sub-Saharan Africa (Ruhr Economic Papers No. 570). Essen, Germany. https://doi.org/10.2139/ssrn.2706469

[42] Strauss, J., Witoelar, F., \& Sikoki, B. (2016). The Fifth Wave of the Indonesia Family Life Survey: Overview and Field Report: Volume 1. California, USA: RAND Corporation. https://doi.org/10.7249/WR1143.1

[43] United Nations. (1994). Declaration on the Elimination of Violence against Women. New York, USA: United Nations.

[44] Venning, P. (2010). Marrying contested approaches: Empowerment and the imposition ofinternational principles: Domestic violence case resolution in Indonesia. Journal of Development Studies, 46(3), 397416. https://doi.org/10.1080/00220380903002913

[45] Wahyuni, S. (2008). Konsep Nusyuz dan Kekerasan Terhadap Isteri: Perbandingan Hukum Positif dan Fiqh. Al-Ahwal, 1(1), 17-30.

[46] World Health Organization. (2002). World report on violence and health. (E. G. Krug, L. L. Dahlberg, J. A. Mercy, A. B. Zwi, \& R. Lozano, Eds.). Geneva, Switzerland: World Health Organization. Retrieved from https://www.who.int/violence injury_prevention/violence /world_report/en/ 